\title{
First report of Trypanosoma cruzi infection in naturally infected dogs from southern Bahia, Brazil
}

\author{
Primeiro relato de infecção natural por Trypanosoma cruzi em cães do sul da Bahia, Brasil \\ Nilo Fernandes Leça Júnior ${ }^{1}$; Valter dos Anjos Almeida ${ }^{1}$; Fábio Santos Carvalho; \\ George Rego Albuquerque; Fabiana Lessa Silva ${ }^{2 *}$
}

${ }^{1}$ Programa de Pós-graduação em Ciência Animal, Universidade Estadual de Santa Cruz - UESC, Ilhéus, BA, Brasil

${ }^{2}$ Departamento de Ciências Agrárias e Ambientais, Universidade Estadual de Santa Cruz - UESC, Ilhéus, BA, Brasil

Received April 25, 2012

Accepted October 8, 2012

\begin{abstract}
In order to verify the Trypanosoma cruzi infection in domestic domiciled dogs in a rural endemic area from the south region of the State of Bahia, Polymerase Chain Reaction (PCR) were performed using S35 and S36 primers in 272 dogs living in the district of Vila Operaria, in the municipality of Buerarema. All animals were clinically evaluated; $2.5 \mathrm{~mL}$ of blood were collected through venipuncture for the performance of molecular tests. None of these animals showed clinical signs of the illness and only two were identified with the DNA parasite. This result is the first report of natural infection by T. cruzi in domestic dogs in southern Bahia.
\end{abstract}

Keywords: Trypanosoma cruzi, dog, PCR, Polymerase Chain Reaction, Bahia.

\section{Resumo}

Com o objetivo de verificar a infecção por Trypanosoma cruzi em cães domésticos domiciliados em área rural e endêmica do sul da Bahia, foi realizada a Reaçâo em Cadeia da Polimerase (PCR), utilizando-se os iniciadores S35 e S36 em 272 cáes domiciliados no distrito da Vila Operária, cidade de Buerarema. Todos os animais foram avaliados clinicamente e, posteriormente, foram coletados $2,5 \mathrm{~mL}$ de sangue por punção venosa para realização do diagnóstico molecular. Nenhum dos animais apresentou manifestação clínica da doença e, em apenas dois foram identificados DNA do parasito. Esse resultado é o primeiro relato de infecçáo natural por T. cruzi em cáes domésticos no sul baiano.

Palavras-chave: Trypanosoma cruzi, cão, PCR, Reação em Cadeia da Polimerase, Bahia.

\section{Introduction}

American trypanosomiasis is a major public health problem in developing countries. This disease is caused by a protozoan parasite that can affect both human and wild or domestic animals. In Brazil, according to Vinhaes and Dias (2000), 36\% of the whole territory presents risks of vectorial transmission. In the northeast region, the State of Bahia holds the highest level of human infection, with seroprevalence rates varying from 5.4 to $25.0 \%$ (CAMARGO et al., 1984; ARAS et al., 2002). The main form of contamination is by the feces of contaminated hematophagous triatomine arthropods (ROSYPAL et al., 2007) however, contamination through experimental breast-feeding (MEDINA LOPES, 1988), blood transfusion (BAHIA et al., 2002), and oral ingestion (YOSHIDA, 2009; SHIKANAI-YASUDA; CARVALHO, 2012) have been reported. Sylvatic and domestic animals play an important role in the life cycle of this parasite.

\section{${ }^{*}$ Corresponding author: Fabiana Lessa Silva}

Departamento de Ciências Agrárias e Ambientais, Universidade Estadual de Santa Cruz - UESC, Rod. Ilhéus Itabuna, Km 16, Salobrinho, CEP 45662-900,

Ilhéus, BA, Brasil

e-mail: fabiana.lessa@gmail.com
Domestic dogs act maintaining the lifecycle of this parasite in the ambience, especially inside their dwellings, because those animals are a frequent source of blood meals for triatomines bugs (GÜRTLER et al., 1997, 2007). In the State of Bahia, previous studies carried out in rural areas verified approximately $19.0 \%$ of dogs infected by T. cruzi - detected by xenodiagnosis (MOTT et al., 1978; BARRET et al., 1979). The main clinical signs observed in sick animals are anorexia, fever, lymphadenopathy and problems related to heart failure (NABITY et al., 2006; GUEDES et al., 2007). The resource tools commonly used to diagnose this disease are the parasitological, immunological and molecular tests. The purpose of the present research was to identify Trypanosoma cruzi infection in dogs in an endemic rural area of southern Bahia, a district with no data of barber bug fever (Chagas disease) in dogs.

\section{Materials and Methods}

The district of Vila Operaria in the municipality of Buerarema (14 $57^{\prime} \mathrm{S}$ and $39^{\circ} 19^{\prime} \mathrm{W}$ ), south region of the State of Bahia, Brazil, is an endemic area for American trypanosomiasis. The 
district is surrounded by the native Atlantic Rainforest and the site of this study presents a strictly rural structure with its main economic resources coming from cocoa farms.

In this study, the whole dog population living in the district was included and all the animals were natural of the area. From the total of 272 animals, 158 (58.08\%) were males and 114 (41.92\%) were females. Initially, the animals were clinically evaluated, then $2.5 \mathrm{~mL}$ of blood was obtained through venipuncture and allocated in Vacutainer ${ }^{\circledR}$ tubes with EDTA in a cooler box to perform molecular tests.

The materials were centrifuged for 15 minutes at $1473.35 \mathrm{G}$ and the leucocitary layers were transferred to micro tubes free of DNAase and RNAase and stored at $-20{ }^{\circ} \mathrm{C}$ until the procedure of DNA extraction.

DNA extraction was performed utilizing phenol-chloroform method as a routine protocol of the Laboratory of Animal Genetics - Veterinary Medicine Hospital - UESC. The material obtained from this procedure was stocked at $-20{ }^{\circ} \mathrm{C}$ until PCR diagnostic test.

PCR amplification was performed in a total volume of $25 \mu \mathrm{L}$ containing $0.4 \mu \mathrm{L}(1.5 \mathrm{U})$ of Taq DNA Polymerase (Invitrogen ${ }^{\circledR}$ ), $17 \mu \mathrm{L}$ of Supermix (Invitrogen ${ }^{\circledR}$ ), $0.6 \mu \mathrm{L}(1.2 \mathrm{mM}$ ) of $\mathrm{MgCl}$, $2 \mu \mathrm{L}$ ( 20 picomol) of each primer, and $3 \mu \mathrm{L}$ of the DNA extract. The sequences of primers used in the PCR reaction were S35: 5' AAATAATGTACGGGGGAGATGCATGA 3' and S36: 5' GGGTTCGATTGGGGTTGGTGT 3'. Those primers amplified a fragment of $330 \mathrm{pb}$. The reaction conditions, such as number of cycles and temperature, were adapted from Ávila et al. (1990). The reactions were performed utilizing 35 cycles and the following temperature profile: denaturation at $94^{\circ} \mathrm{C}$ for 1 minute (initializing with a maximum period of 5 minutes at $94^{\circ} \mathrm{C}$ ), $65^{\circ} \mathrm{C}$ for 1 minute for primer annealing and $72{ }^{\circ} \mathrm{C}$ for 1 minute for extension, and final incubation for 7 minutes at $72{ }^{\circ} \mathrm{C}$. The amplified DNA was visualized with $2 \%$ agarose gel, revealed with bromide ethidium $(10 \mathrm{mg} / \mathrm{mL})$, and photo documented. All PCR reactions were compared to positive and negative controls. The positive controls were obtained from pure culture of T. cruzi Y strain and ultra-pure water was used for the negative control.

This study is consistent with ethical principles of animal experimentation. It was approved and authorized by the Animal Ethic Committee from the "Universidade Estadual de Santa Cruz" - UESC, (Protocol no. 002/10).

\section{Results and Discussion}

From the 272 dogs studied, only two (0.7\%) animals, one male and one female, were positive in the molecular diagnosis for DNA from T. cruzi parasite (Figure 1).

At the clinical exam, no sign of the disease was observed in the dog population. Machado et al. (2001) observed dogs that did not show clinical evidence of the disease even after five episodes of reinfection and dogs that presented only sporadic febrile state during the first weeks after each inoculation.

The available data on the incidence of $T$. cruzi infection in dogs are based on immunological tests, once there are no epidemiological studies based on PCR. In Brazil, data from dogs in the State of

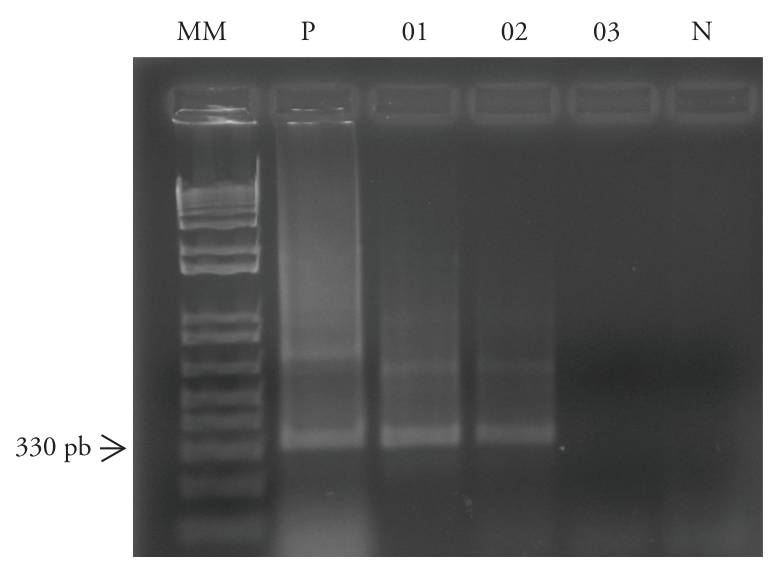

Figure 1. Representative result of the PCR for detection of T. cruzi in blood samples of dogs living in the district of Vila Operária, city of Buerarema. $\mathrm{MM}=$ Molecular Marker; $\mathrm{P}$ = Positive Control (culture of T. cruzi - Y strain); 01 to 03 : dog samples; $\mathrm{N}=$ Negative control (ultra-pure water). Observe band presence in the animals 01 and 02 .

Mato Grosso do Sul, an endemic autochthone area for human Chagas disease, showed $45.3 \%$ and $24.0 \%$ of infection in domiciled animals with IFI (indirect immunofluorescence test) and ELISA (enzyme-linked immunosorbent assay), respectively (SOUZA et al., 2009). However, in the State of Sao Paulo, 107 serum samples from euthanized dogs were tested by IFI, revealing no positive titers for T. cruzi infection (ROSYPAL et al., 2007). This wide range observed in the results obtained by immunological tests that have high sensibility and low specificity can be explained by previous related cross reaction, in humans and dogs, between Leishmania spp. and T. cruzi infections (LUCIANO et al., 2009).

Molecular tests such as PCR provide a good alternative tool for detection of T. cruzi infection in animal samples. The values observed with this technique, in experimental studies with dogs, reached more than 90\% using blood or others tissues (ARAÚJO et al., 2002; VELOSO et al., 2008). Veloso et al. (2008) obtained the highest levels in identifying parasitized experimentally infected Beagle dogs that were in the acute phase of infection, when the parasitemia levels were high. The low incidence observed in this study can be explained by the fact that those animals were possibly on the chronic phase of the infection or were not really infected.

In Brazil, since the 1990's, the Brazilian National Health Foundation (FUNASA) has enforced intensive control measures on the Triatoma infestans population through insecticide spraying. The result of this control program was the widespread reduction of $T$. cruzi transmission by this triatomine bug, considered the most important vector of Chagas disease in the past (SILVEIRA; VINHAES, 1999; DIAS, 2006). In 2006, the Pan American Health Organization (PAHO) certified the interruption of T. cruzi transmission by T. infestans in Brazil (BRASIL, 2006). Nevertheless, according to the Brazilian Health Minister (BRASIL, 2005), the State of Bahia is the only one in the country that still presents infestation by $T$. infestans, with 93 of the 417 municipalities situated in risk areas or presenting the vectors over the past years. Moreover, there are reports that suggest the participation of triatomine bugs, otherwise considered sylvatic, in the transmission of the disease 
in that state, for instance T. pseudomaculata, T. tibiamaculata and T. brasiliensis (ALMEIDA et al., 2009; DIAS-LIMA; SHERLOCK, 2000; WALTER et al., 2005; SANTANA et al., 2011). Besides, this data suggest the maintenance of vectorial importance in T. cruzi transmission in that region. Thus, in spite of the low infection prevalence observed in this research, these data are important, once infected dogs can act as T. cruzi reservoirs.

This is the first report of infected dogs in southern Bahia. It is an important finding because it suggests that those dogs can act in the life cycle of $T$. cruzi parasite in an endemic area for the disease, being a risk factor to contaminate triatomine bugs and then humans.

\section{Acknowledgements}

We thank Danielle Oliveira dos Anjos, who kindly yielded us the Trypanosoma cruzi Y strain to our research.

\section{References}

Almeida CE, Folly-Ramos E, Peterson AT, Lima-Neiva V, Gumiel $\mathrm{M}$, Duarte R, et al. Could the bug Triatoma sherlocki be vectoring Chagas disease in small mining communities in Bahia, Brazil? Med Vet Entomol 2009, 23(4): 410-417. PMid:19941607. http://dx.doi. org/10.1111/j.1365-2915.2009.00822.x

Aras R, Veiga M, Gomes I, Mota G, Rodrigues B, Rabelo R, et al. Prevalence of Chagas' disease in Mulungu do Morro, Northeastern Brazil. Arq Bras Cardiol 2002: 78(5): 441-443. PMid:12045842. http://dx.doi. org/10.1590/S0066-782X2002000500001

Araújo FMG, Bahia MT, Magalhães NM, Martins-Filho OA, Veloso VM, Carneiro CM, et al.Follow-up of experimental chronic Chaga's disease in dogs: use of polymerase chain reaction (PCR) compared with parasitological and serological methods. Acta Trop 2002; 81(1): 21-31. http://dx.doi.org/10.1016/S0001-706X(01)00196-6

Ávila H, Gonçalves AM, Nehme NS, Morel CM, Simpson L. Schizodeme analysis of Trypanosoma cruzi stocks from South and Central America by analysis of PCR-amplified minicircle variable region sequences. $\mathrm{Mol}$ Biochem Parasitol 1990; 42(2): 175-188. http://dx.doi.org/10.1016/01666851(90)90160-N

Bahia MT, Tafuri WL, Caliari MV, Veloso VM, Carneiro CM, MachadoCoelho GLL, et al. Comparison of Trypanosoma cruzi infection in dogs inoculated with blood or metacyclic trypomastigotes of Berenice- 62 and Berenice-78 strains via intraperitoneal and conjunctival routes. Rev Soc Bras Med Trop 2002; 35(4): 339-345. PMid:12170329. http://dx.doi. org/10.1590/S0037-86822002000400010

Barret TV, Hoff R, Mott KE, Guedes F, Sherlock IA. An outbreak of acute Chagas's disease in the Sấo Francisco Valley region of Bahia, Brazil: triatomine vectors and animal reservoirs of Trypanosoma cruzi. Trans $R$ Soc Trop Med Hyg 1979; 73(6): 703-709. http://dx.doi.org/10.1016/00359203(79)90025-7

Brasil. Ministério da Saúde. Secretaria de Vigilância em Saúde. Sistema Nacional deVigilância em Saúde. Brasília, 2005. Relatório de Situação. Série C. Projetos, Programas e Relatórios. [cited 2012 Aug 23]. Available from: http://bvsms.saude.gov.br/bvs/publicacoes/ba1.pdf.

Brasil. Ministério da Saúde. Secretaria de Vigilância em Saúde. Brasil receberá certificado internacional da interrupção da transmissão vetorial da Doença de Chagas pelo Triatoma Infestans. Brasília, 2006 [cited 2012 Aug 23]. Available from: http://portal.saude.gov.br/portal/arquivos/pdf/ notatecnica_chagas0806.pdf.

Camargo ME, Silva GR, Castilho EA, Silveira AC. Inquérito sorológico da prevalência de infecção chagásica no Brasil, 1975/1980. Rev Inst Med Trop São Paulo 1984, 26: 192-204. PMid:6441232.

Dias JCP. Doença de Chagas: sucessos e desafios. Cad Saúde Pública 2006; 22(10): 2020-2021. PMid:16951867. http://dx.doi. org/10.1590/S0102-311X2006001000001

Dias-Lima AG, Sherlock IA. Sylvatic vectors invading houses and the risk of emergence of cases of Chagas Disease in Salvador, State of Bahia, Northeast Brazil. Mem Inst Oswaldo Cruz 2000, 95(5): 611-613. PMid:10998208. http://dx.doi.org/10.1590/S0074-02762000000500004

Guedes PMM, Veloso VM, Caliari MV, Carneiro CM, Souza SM, Lana M, et al. Trypanosoma cruzi high infectivity in vitro is related to cardiac lesions during long-term infection in Beagle dogs. Mem Inst Oswaldo Cruz 2007; 102(2): 141-147. PMid:17426876. http://dx.doi. org/10.1590/S0074-02762007005000003

Gürtler RE, Cohen JE, Cecere MC, Chuit R. Shifting host choices of the vector of Chagas disease, Triatoma infestans, in relation to the availability of hosts in houses in north-west Argentina. J App Ecol 1997; 34(3): 699-715. http://dx.doi.org/10.2307/2404917

Gürtler RE, Cecere MC, Lauricella MA, Cardinal MV, Kitron U, Cohen JE. Domestic dogs and cats as sources of Trypanosoma cruzi infection in rural northwestern Argentina. Parasitology 2007; 134(1): 69-82. PMid:17032467 PMCid:2669415. http://dx.doi.org/10.1017/ S0031182006001259

Luciano RM, Lucheis SB, Troncarelli MZ, Luciano DM, Langoni H. Avaliação da reatividade cruzada entre antígenos de Leishmania spp e Trypanosoma cruzi na resposta sorológica de cáes pela técnica de imunofluorescência indireta (RIFI). Braz J Vet Res Anim Sci 2009; 46(3):181-187.

Machado EMM, Fernandes AJ, Murta SMF, Vitor RWA, Camilo Junior DJ, Pinheiro SW, et al. A study of experimental reinfection by Trypanosoma cruzi in dogs. Am J Trop Med Hyg 2001; 65(6): 958-965. PMid:11792006.

Medina Lopes MD. Transmissão do Trypanosoma cruzi em um caso, durante aleitamento, em área não endêmica. Rev Soc Bras Med Trop 1988, 21(3): 151-153.

Mott KE, Mota EA, Sherlock IA, Hoff R, Muniz TM, Oliveira TS, et al. Trypanosoma cruzi infection in dogs and cats and household seroreactivity to T. cruzi in a rural community in northeast Brazil. Am J Trop Med Hyg 1978; 27(6): 1123-1127. PMid:103446.

Nabity MB, Barnhart KS, Logan KS, Santos RL, Kessel A, Melmed C, et al. An atypical case of Trypanosoma cruzi infection in a young English Mastiff. Vet Parasitol 2006; 140(3-4): 356-361. PMid:16716519. http:// dx.doi.org/10.1016/j.vetpar.2006.03.034

Rosypal AC, Cortés-Vecino JA, Gennari SM, Dubey JP, Tidwell RR, Lindsay DS. Serological survey of Leishmania infantum and Trypanosoma cruzi in dogs from urban areas of Brazil and Colombia. Vet Parasitol 2007; 149(3-4): 172-177. PMid:17825991 PMCid:2238727. http://dx.doi.org/10.1016/j.vetpar.2007.08.004

Santana KSO, Bavia ME, Lima AD, Guimarães ICS, Soares ES, Silva MMN, et al. Spatial distribution of triatomines (Reduviidae: Triatominae) in urban areas of the city of Salvador, Bahia, Brazil. Geospatl Health 2011; 5(2): 199-203. 
Shikanai-Yasuda MA, Carvalho NB. Oral transmission of Chagas Disease. Clin Infect Dis 2012; 54(6): 845-852. PMid:22238161. http://dx.doi. org/10.1093/cid/cir956

Silveira AC, Vinhaes MC. Elimination of vector-borne transmission of Chagas disease. Mem Inst Oswaldo Cruz 1999; 94(S1): 405-411. PMid:10677766. http://dx.doi.org/10.1590/S007402761999000700080

Souza AI, Oliveira TMFS, Machado RZ, Camacho AA. Soroprevalência da infecção por Trypanosoma cruzi em cáes de uma área rural do Estado de Mato Grosso do Sul. Pesq Vet Bras 2009; 29(2): 150-152. http://dx.doi. org/10.1590/S0100-736X2009000200011

Veloso VM, Guedes PMM, Andrade IM, Caldas IS, Martins HR, Carneiro $\mathrm{CM}$, et al. Trypanosoma cruzi: blood parasitism kinetics and their correlation with heart parasitism intensity during long-term infection of Beagle dogs. Mem Inst Oswaldo Cruz 2008; 103(6): 528-534. PMid:18949320. http:// dx.doi.org/10.1590/S0074-02762008000600003

Vinhaes MC, Dias JCP. Doença de Chagas no Brasil. Cad Saúde Pública 2000; 16(S2): 7-12. PMid:11119316. http://dx.doi.org/10.1590/ S0102-311X2000000800002

Walter A, Rego IP, Ferreira AJ, Rogier C. Risk factors for reinvasion of human dweliings by sylvatic triatomines in northern Bahia State, Brazil. Cad Saúde Pública 2005; 21(3): 974-978. PMid:15868058. http://dx.doi. org/10.1590/S0102-311X2005000300034

Yoshida N. Molecular mechanisms of Trypanosoma cruzi infection by oral route. Mem Inst Oswaldo Cruz 2009; 104(S1): 101-107. PMid:19753464. http://dx.doi.org/10.1590/S0074-02762009000900015 